\title{
PENAMBAHAN TEPUNG DAUN KELOR (Moringa oleifera) DAN TEPUNG KACANG KEDELAI (Glycine max. L) TERHADAP NILAI GIZI SNACK BAR
}

\author{
[Addition of Moringa Leaf Flour (Moringa oleifera) and Soybean Flour (Glycine max. L) on Nutritional \\ Value of Snack Bar]
}

\author{
Dylla Hanggaeni Dyah Puspaningrum ${ }^{1{ }^{*}}$, Ida Ayu Ida Srikulini ${ }^{1)}$, Ni Ketut Wiradnyani ${ }^{1)}$ \\ 1)Program Studi Ilmu Gizi, Fakultas Ilmu Kesehatan, Sains, dan Teknologi, Universitas Dhyana Pura \\ * Email : dyllahanggaeni@undhirabali.com
}

Diterima 29 Agustus 2019 / Disetujui 20 Desember 2019

\begin{abstract}
Moringa leaf flour (Moringa olefera) and soybean flour (Glicine Max. L) is a food that has high nutrient content. The presence of these contents is good to be used as ingredients for making snack bar that are rich in nutrients. This study used a complete randomized trial (RAL) with five types of treatment and three replications. Data analysis used anova test with $L S D$ and Duncan test. The treatment that used to the moringa leaf flour and soybean flour in snack bar are K1P1 (0:100\%), K2P2 (25:75\%), K3P3 (15:15\%), K4P4 (75:25\%), K5P5 (0:100\%). The analysis carried out was an analysis of nutrient content. The results showed that the higher addition of soybean flour would affect the protein and fat content. The carbohydrate content is influenced by other components. Iron will be affected by the addition of moringa leaf flour.
\end{abstract}

Key words: snack bar, moringa leaf flour, soybean flour, nutrient content

\section{ABSTRAK}

Tepung daun kelor (Moringa olefera) dan tepung kacang kedelai (Glicine Max. L) merupakan bahan pangan yang tinggi kandungan gizi. Terdapatnya kandungan tersebut baik digunakan sebagai bahan pembuatan snack bar yang kaya akan zat gizi.Penelitian ini menggunakan Rancangan Acak Lengkap (RAL) dengan lima jenis perlakuan dan tiga kali ulangan. Analisis data menggunakan uji Anova dengan uji lanjut $L S D$ dan Ducan. Perlakuan pada snack bar tepung daun kelor dan tepung kacang kedelai yaitu K1P1 (0:100\%), K2P2 (25:75\%), K3P3 $(15: 15 \%)$, K4P4 $(75: 25 \%)$, K5P5 (0:100\%). Analisis yang dilakukan adalah analisis kandungan zat gizi. Hasil penelitian menunjukkan bahwa semakin tingginya penambahan tepung kacang kedelai maka akan mempengaruhi kandungan protein dan lemak. Kandungan karbohidrat dipengaruhi oleh kandungan komponen yang lain. Kandungan zat besi akan dipengaruhi oleh penambahan tepung daun kelor.

Kata kunci: snack bar, tepung daun kelor, tepung kacang kedelai, nilai gizi

\section{PENDAHULUAN}

Snack bar merupakan salah satu makanan ringan yang disukai oleh remaja. Snack bar termasuk kedalam makanan yang praktis dan memiliki nilai gizi yang lengkap dan termasuk kedalam makanan yang awet bila disimpan (Syahwal dkk, 2018).

Daun kelor merupakan daun yang berasal dari pohon kelor. Daun kelor merupakan salah satu bahan makanan yang mengandung nutrisi penting seperti vitamin $A$, vitamin $C$, vitamin $B$, kalsium, kalium, protein serta zat besi (Yulianti dkk, 2016).
Cara konsumsi daun kelor dapat dengan berbagai cara seperti dikonsumsi dalam bentuk segar, bentuk minuman, dan olahan daun kelor yang lain seperti olahan dalam bentuk tepung (Purba, 2018). Kandungan zat besi pada 100 gram daun kelor yaitu $7 \mathrm{mg}$, apabila ditepungkan maka kandungan zat besinya mencapai 28,2 mg (Sari dkk, 2017). Kandungan nutrisi yang mendasar pada tepung daun kelor adalah karbohidrat, zat besi dan mengandung protein. Untuk dapat meningkatkan mutu pada snack barmaka salah satu bahan makanan yang dapat ditambahkan adalah tepung kacang kedelai. 
Kacang kedelai termasuk bahan makanan yang mengandung protein nabati. Kacang kedelai juga dapat dimodifikasikan menjadi tepung, dengan memodifikasi menjadi tepung maka akan meningkatkan keunggulan, yaitu dapat menghilangkan cita rasa langu dan dapat meningkatkan keawetan (Astawan dkk, 2016).

Kandungan protein pada kacang kedelai mencapai 34,90 gram dan apabila ditepungkan maka kandungan protein tepung kacang kedelai akan mencapai 45,8663\% (Wiranata, 2017).

Berdasarkan penelitian yang pernah ada menggunakan snack bar dengan bahan dasar tepung kacang kedelai dan tepung kacang merah yang digunakan sebagai makanan pasien kemoterapi, dalam penelitian tersebut didapatkan formulasi terbaik yang terdapat pada snack bar dengan penambahan tepung kacang kedelai $25 \%$ dan kacang merah $75 \%$. Formulasi tersebut menghasilkan snack bar dengan kandungan zat gizi energi 232,18 kkal, protein $12,75 \mathrm{~g}$, lemak $4,71 \mathrm{~g}$, karbohidrat $35,36 \mathrm{~g}$ dan antioksidan $84,69 \mathrm{mg} / \mathrm{L}$ GAEAC (Wiranata, 2017).

Berdasarkan penelitian yang menggunakan tepung daun kelor dan tepung kecambah kedelai yang diolah menjadi cookies, menghasilkan formulasi terbaik dengan penambahan tepung daun kelor $10 \mathrm{gram}$ dan tepung kecambah kedelai 40 gram, dimana dalam formulasi ini menghasilkan cookies dengan kadar protein dan zat besi per $100 \mathrm{~g}$ secara berturut-turut adalah $9 \mathrm{~g}$ dan 3,88 $\mathrm{mg}$ (Sari dkk, 2017). Namun pemilihan bahan baku snack barmenggunakan tepung daun kelor dan tepung kacang kedelai belum pernah diteliti. Penelitian ini bertujuan untuk mengetahui nilai gizi snack bar yang ditambahkan tepung daun kelor dan tepung kacang kedelai.

\section{BAHAN DAN METODE}

\section{Bahan}

Bahan baku pembuatan snack bar yaitu: tepung daun kelor (kedai kelor) dan tepung kacang kedelai (Gasol), susu bubuk full cream (Indomilk), oat (Rolled Oat), rice crispy
(Kellogg's), cokelat (Collata), madu (Madu Tj), kismis (Raisins), gula merah, putih telur. Bahan kimia yang digunakan untuk analisis kandungan zat gizi (kadar air, kadar abu, protein, lemak dan $\mathrm{Fe}$ ) adalah $\mathrm{K}_{2} \mathrm{SO}_{4}, \mathrm{HgO}, \mathrm{H}_{2} \mathrm{SO}_{4}, \mathrm{NaOH}-$ $\mathrm{Na}_{2} \mathrm{~S}_{2} \mathrm{O}_{3}, \mathrm{H}_{3} \mathrm{BO}_{3}, \mathrm{HCL}$, aqua dest, $\mathrm{NaOH}, \mathrm{HNO}_{3}$, $\mathrm{HCL}$ dan kertas saring. Alat yang digunakan dalam penelitan ini Oven, desikator, timbangan cawan porselin, hot plate, tanu listrik, labu kjedhal, erlemeyer, labu lemak, soxhlet, tabung reaksi, pipet, spektofotometer serapan atom

\section{Metode}

Penelitian ini termasuk kedalam penelitian ekperimental dengan rancangan acak lengkap. Peneltian ini menggunakan 5 jenis perlakuan dengan 3 kali pengulangan. Perlakuan yang dimaksud adalah sebagai berikut (Wiranata, 2017):

1. $\mathrm{K}_{1} \mathrm{P}_{1}$ : Tepung daun kelor $0 \%$ : tepung kacang kedelai $100 \%$

2. $\mathrm{K}_{2} \mathrm{P}_{2}$ : Tepung daun kelor $25 \%$ : tepung kacang kedelai $75 \%$

3. $\mathrm{K}_{3} \mathrm{P}_{3}$ : Tepung daun kelor $50 \%$ : tepung kacang kedelai $50 \%$

4. $\mathrm{K}_{4} \mathrm{P}_{4}$ : Tepung daun kelor $75 \%$ : tepung kacang kedelai $25 \%$

5. $\mathrm{K}_{5} \mathrm{P}_{5}$ : Tepung daun kelor $100 \%$ : tepung kacang kedelai $0 \%$

Parameter yang diamati dalam penelitian meliputi uji kandungan gizi kadar air, kadar abu, protein, lemak, karbohidrat dan zat besi. Perlakuan kemudian akan dianalisis normalitas dengan menggunakan kolmogorov-smirnov dan sidik ragam (ANOVA) untuk mengetahui pengaruh perlakuan terhadap parameter yang diuji. Apabila ada pengaruh maka akan dilanjutkan dengan uji lanjut $L S D$ dan Ducan.

\section{Tahap Pembuatan Snack Bar}

Timbang bahan - bahan seperti tepung daun kelor, tepung kacang kedelai, tapung susu, oat, rice crispy, kacang hijau, kismis, madu, gula merah, cokelat. Rebus kacang hijau dan dihaluskan. Pada adonan petama dicampur tepung daun kelor, tepung kacang kedelai, tepung susu, oat, kacang hijau, putih telur, dan kismis. Pada adonan ke dua campurkan rice crispy, madu dan gula merah yang telah dicairkan. Adonan pertama diletakkan dalam 
loyang kemudian pada bagian atas diletakkan adonan ke dua, kemudian dimasukkan kedalam oven dengan suhu $150^{\circ} \mathrm{C}$ selama 45 menit, setelah matang dibiarkan dingin lalu dipotong menjadi persegi panjang. Ditambahkan cokelat pada bagian bawah snack bar. Cokelat dibiarkan hingga mengeras.

\section{HASIL DAN PEMBAHASAN}

\section{Kadar Air}

Snack bar tepung daun kelor dan tepung kacang kedelai dengan kandungan kadar air tertinggi terdapat pada perlakuan K5P5 yaitu 25,8059\%. Nilai kadar air terendah terdapat pada perlakuan K2P2 yaitu 23,9283\%. Kandungan kadar air yang tinggi dapat menyebabkan penurunan kesegaran dan daya tahan terhadap produk, hal ini disebabkan karena kadar air yang tinggi menyebabkan bakteri, kapang dan khamir akan lebih mudah berkembang biak dan menyebabkan produk lebih mudah rusak dan busuk (Winata dkk, 2015).

Tabel 1. Analisis Kadar Air Kadar Abu

\begin{tabular}{lll}
\hline Perlakuan & \multicolumn{2}{c}{ Analisis } \\
\cline { 2 - 3 } & Kadar Air & \multicolumn{1}{c}{ Kadar Abu } \\
\hline K1P1 & $25,3687^{\mathrm{b}} \pm$ & $2,8751^{\mathrm{b}} \pm$ \\
& 0,0615 & 0,05855 \\
K2P2 & $23,9283^{\mathrm{a}} \pm$ & $3,0219^{\mathrm{c}} \pm$ \\
& 0,7206 & 0,02565 \\
K3P3 & $25,8023^{\mathrm{b}} \pm$ & $2,7210^{\mathrm{a}} \pm$ \\
& 0,6012 & 0,04956 \\
K4P4 & $25,6600^{\mathrm{b}} \pm$ & $4,0501^{\mathrm{e}} \pm$ \\
& 0,1130 & 0,07858 \\
K5P5 & $25,8059^{\mathrm{b}} \pm$ & $3,5030^{\mathrm{d}} \pm$ \\
& 0,1062 & 0,03807 \\
\hline
\end{tabular}

\section{Protein}

Snack Bartepung daun kelor dan tepung kacang kedelai dengan kandungan protein tertinggi terdapat pada perlakuan K1P1 yaitu $28,9632 \%$, nilai protein terendah terdapat pada perlakuan K5P5 yaitu 10,1619\%. Kandungan protein snack bar cenderung meningkat bersamaan dengan penambahan tepung kacang kedelai yang tinggi didalam snack bar, ini disebabkan karena kandungan protein kacang kedelai lebih tinggi mencapai $45,86 \%$ (Wiranata, 2017) dibandingkan dengan tepung daun kelor berkisar 26,02\% (Augustyn dkk, 2017).

\section{Kadar Abu}

Snack bar tepung daun kelor dan tepung kacang kedelai dengan kandungan kadar abu tertinggi terdapat pada perlakuan K4P4 yaitu $4,0501 \%$. Nilai kadar abu terendah terdapat pada perlakuan K3P3 yaitu 2,7210\%. Tingginya nilai kadar abu dapat disebabkan karena suhu serta lamanya pemanggangan, hal ini disebabkan karena semakin lama pengeringan yang dilakukan terhadap bahan maka jumlah air yang teruapkan dari dalam bahan yang dikeringkan akan semakin besar (Erni dkk, 2018).

Tabel 2. Analisis Nilai Gizi

\begin{tabular}{lllll}
\hline Perlakuan & Protein & Lemak & Karbohidrat & Zat besi \\
\hline K1P1 & $28,9632^{\mathrm{e}}$ & $20,0006^{\mathrm{e}}$ & $22,7914^{\mathrm{a}} \pm$ & $55,9773^{\mathrm{a}}$ \\
& $\pm 0,4631$ & $\pm 0,0659$ & 0,4802 & $\pm 1,3573$ \\
K2P2 & $20,3079^{\mathrm{d}}$ & $14,4408^{\mathrm{d}}$ & $38,6345^{\mathrm{b}} \pm$ & $89,3670^{\mathrm{c}}$ \\
& $\pm 0,3443$ & $\pm 0,0775$ & 0,1337 & $\pm 1,8048$ \\
K3P3 & $17,6703^{\mathrm{c}}$ & $12,0446^{\mathrm{c}} \pm$ & $41,7619^{\mathrm{c}} \pm$ & $74,2383^{\mathrm{b}}$ \\
& $\pm 0,1695$ & 0,1358 & $0,3339^{-}$ & $\pm 2,8122$ \\
K4P4 & $13,3200^{\mathrm{b}}$ & $9,7006^{\mathrm{b}} \pm$ & $47,2633^{\mathrm{d}} \pm$ & $108,8117^{\mathrm{d}}$ \\
& $\pm 0,1425$ & 0,2039 & $0,1439^{\mathrm{a}}$ & $\pm 0,5988$ \\
K5P5 & $10,1619^{\mathrm{a}}$ & $5,7991^{\mathrm{a}} \pm$ & $54,7302^{\mathrm{e}} \pm$ & $109,3810^{\mathrm{d}}$ \\
& $\pm 0,2225$ & 0,1024 & 0,1560 & $\pm 1,7973$ \\
\hline
\end{tabular}

\section{Lemak}

Snack Bartepung daun kelor dan tepung kacang kedelai dengan kandungan lemak tertinggi terdapat pada perlakuan K1P1 yaitu $20,0006 \%$, nilai lemak terendah terdapat pada perlakuan K5P5 yaitu $5,7991 \%$.

Kandungan lemak pada tepung daun kelor berkisar 2,52\% (Augustyn dkk, 2017) sedangkan kandungan tepung kacang kedelai lebih besar yaitu 9,3083\% (Wiranata,2017). Proses pemanggangan snack bar tepung daun kelor dan tepung kacang kedelai juga mempengaruhi kandunga lemak, hal ini disebabkan karena protein dalam produk apabila dipanaskan maka akan terkoagulasi dan menyebabkan banyak air dan lemak yang keluar (Widsor, 2001 dalam Risnawati,2015).

\section{Karbohidrat}

Snack bar tepung daun kelor dan tepung kacang kedelai kandungan karbohidrat tertinggi 
terdapat pada perlakuan K5P5 yaitu 54,7302\%, nilai karbohidrat terendah terdapat pada perlakuan K1P1 yaitu 22,7914\%. Analisis kadar karbohidrat dilakukan dengan metode by different sehingga nilai yang dihasilkan tergantung dari jumlah komponen seperti kandungan kadar abu, air, protein dan lemak. Hasil analisis menunjukkan bahwa kandungan protein dan lemak tinggi sehingga menurunkan kadar karbohidrat snack bar tepunng daun kelor dn tepung kacang kedelai (Winata dkk, 2015).

\section{Zat Besi}

Snack bar tepung daun kelor dan tepung kacang kedelai dengan kandungan zat besi tertinggi yaitu $109,3810 \mathrm{ppm}$ terdapat pada perlakuan K5P5, nilai zat besi terendah yaitu 55,9773 ppm terdapat pada perlakuan K1P1.

Semakin tinggi penambahan tepung daun kelor maka semakin tinggi pula kandungan zat besinya, hal ini disebabkan karena kandungan zat besi dalam 100 gram daun kelor yaitu $7 \mathrm{mg}$, apabila ditepungkan menjadi 28,2 mg (Sari dkk, 2017). Berdasarkan besarnya kandungan zat besi pada tepung daun kelor diketahui bahwa tepung daun kelor mempuyai pengaruh peningkatan zat besi pada snack bar tepung daun kelor dan tepung kacang kedelai.

Kandungan zat besi pada makanan dibagi menjadi 3 kelompok yaitu makanan dengan kandungan gizi rendah kurang dari 0,7 $\mathrm{mg}$ (besi/1000 kal), makanan dengan kandungan gizi sedang yaitu antara $0,7-1,9 \mathrm{mg}$ (besi/1000 kal), dan makanan dengan kandungan besi tinggi yaitu lebih dari 2,0 mg (besi/1000 kal) (British Nutrition Foundtion, 1995 dalam Lailiyana, 2012).

\section{KESIMPULAN}

Kandungan protein dan lemak tertinggi terdapat pada perlakuan K1P1 dengan kandungan protein 28,9632\% dan kandungan lemak 20,0006\%. Kandungan protein dan lemak terendah terdapat pada K5P5 dengan kandungan protein $10,1619 \%$ dan kandungan lemak 5,7991\%.
Kandungan karbohidat dan zat besi tertinggi terdapat pada K5P5 dengan kandungan nilai karbohidrat $54,7302 \%$ dan kandungan zat besi 109,3810 ppm. Kandungan karbohidrat dan zat besi terendah terdapat pada K1P1 dengan kandungan karbohidrat $22,7914 \%$ dan kandungan zat besi 55,9773 ppm

\section{DAFTAR PUSTAKA}

Astawan, M dan Hazmi, K. 2016. Karakteristik Fisikokimia Tepung Kecambah Kedelai. Jurnal Pangan 25 (2): 105-112.

Augustyn H.G., Tuhumury D H.C dan Dahoklory, M. 2017. Pengaruh Penambahan Tepung daun Kelor (Moringa oleifera) Terhadap Karakteristik Organoleptik dan Kimia Biskuit Mocaf (Modified cassava flour). Jurnal Teknologi Pertanian 6(2): 52-58.

Erni, N., Kidarman dan Fadilah, R.. 2018. Pengaruh suhu dan Lama Pengeringan Terhadap Sifat Kimia dan Organoleptik Tepung Umbi Talas (Colocasia esculenta). Jurnal Pendidikan Teknologi Pangan 4: 95-105.

Lailiyana. 2012. Analisis Kandungan Zat Gizi dan Uji Hedonik Cookies Kaya Gizi Pada Siswi SMPN 27 Pekanbaru. Skripsi. Fakultas Kesehatan Masyarakat Universitas Indonesia.

Purba, R.A. 2018. Pengaruh Penambahan Tepung Daun Kelor (Moringa olefiera) Dalam Pembuatan Onde-Onde Ketawa Menggunakan Tepung Mocaf. Skripsi. Fakultas Pertanian Universitas Sumatra Utara.

Risnawati, Y. 2015. Komposisi Proksimat Tempe yang Dibuat Dari Kedelai Lokal dan Kedelai Impor. Skripsi. Program Studi Ilmu Gizi Universitas Muhammadiyah Surakarta.

Sari, K.Y. dan Adi, C.A. 2017. Daya Terima Kadar Protein dan Zat Besi Cookies Subtitusi Tepung Daun Kelor dan Tepung Kecambah Kedelai. Jurnal Media Gizi Indonesia 17(1): 27-33.

Syahwal, S dan Dewi, Z. 2018. Pemberian Snack Bar Meningkatkan Kadar Hemoglobin (HB) Pada Remaja Putri. Aceh Nutrition Journal, 3(1): 9-15. 
Yulianti, H, Hadju, V dan Alasiry, E. 2016. Pengaruh Ekstrak Daun Kelor Terhadap Peningkatan Kadar Hemoglobin Pada Remaja Putri Di SMU Muhhamadiyah Kupang. JST Kesehatan, 6 (3): 399-404.

Wiranata, G.A. 2017. Formulasi dan Karakteristik Nutrimat Bar Berbasis Tepung Kacang Kedelai (Glycine max. L) dan Tepung Kacang Merah (Phaseolusn vulgaris. L) Sebagai Makanan Pasien Kemoterapi. Skripsi. Fakultas IImu Kesehatan, Sains dan Teknologi Program Studi Gizi.

Winata,A., Yualiati, K. dan Hanggita, S. 2015. Analisis Korelasi Harga dan Mutu Kimiawi Krupuk di Pasar Tradisional Cinde Palembang. Jurnal Teknologi Hasil Perikanan, 4(2): 170-183. 